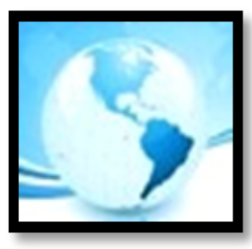

MALAYSIAN ONLINE JOURNAL OF

EDUCATIONAL MANAGEMENT

(MOJEM)

January 2019, VOLUME 7, ISSUE 1, 20 - 36

E-ISSN NO: $2289-4489$

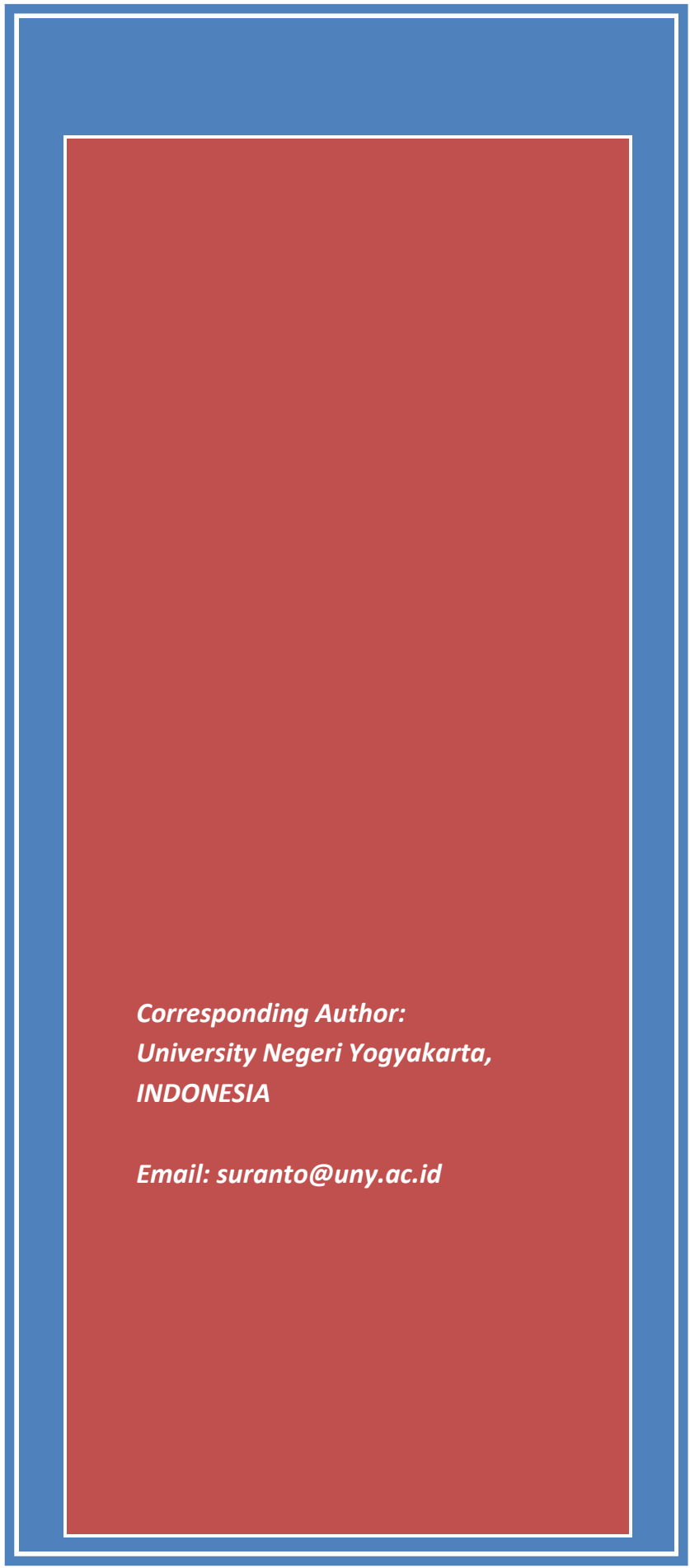

\title{
DEVELOPING AN EVALUATION INSTRUMENT FOR ASSESSING PUBLIC RELATION PRACTITIONER PERFORMANCE IN EDUCATIONAL INSTITUTIONS
}

Suranto Aw (PhD)

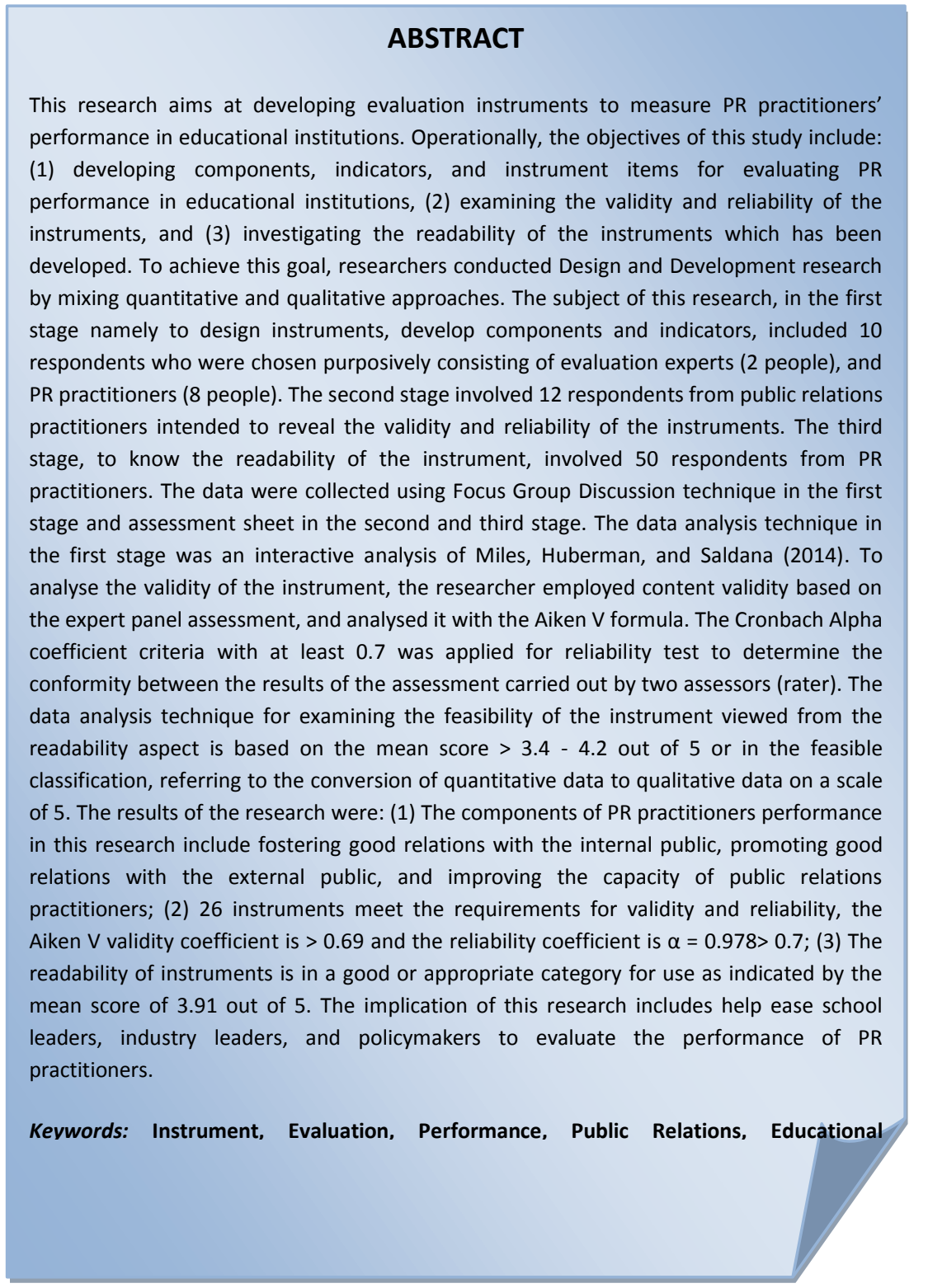




\section{MALAYSIAN ONLINE JOURNAL OF EDUCATIONAL MANAGEMENT (MOJEM)}

\section{INTRODUCTION}

The global development has reinforced educational institutions to constantly improve the quality of its services. This improvement will lead to the increase of global competitiveness which can be realized by improving the quality of educational services. Therefore, improving the quality of education has become the main priority for all countries. Various efforts are taken such as policy making, curriculum reconstruction, inducing teaching and learning situations. Previous researches have shown that it is the schools' priority to provide a quality education through producing graduates who have excellent competencies appropriate to the needs of society and the working world (Zaki \& Rashidi, 2013; Ansari, 2017; Petrovskiy \& Agapova, 2016).

The Indonesian educational system has undergone many substantial changes in order to make sure its quality is as equal to developed countries. Various problems have been studied and the right solutions have been taken to overcome those problems. One of the problems of education in Indonesia is the gap between student learning outcomes and the competencies required by industry (Narayanan \& Nandi, 2017). Indonesia has been undergoing many efforts to improve the quality of education. The National Education Planning Document states that the period of 2015-2020 is referred to as a period of regional competitiveness, which mandates the management of education to focus on the quality of education that promote regional competitiveness at the ASEAN level. Furthermore, the period of 2020-2025 also focuses on competitive education at the global level. This plan indicates the high commitment undertaken by the Indonesian government in order to obtain and sustain a quality education. To ensure this, a consistent evaluation which intends to observe the success of educational programs' implementation in Indonesia is needed. One of the programs prioritized to improve competitiveness is performing partnership programs between educational institutions and various stakeholders, especially with industries. With this partnership, the industry has the opportunity to formulate the desired human resources qualification standard. Meanwhile, the educational institution can use the standard developed by the industry as a reference in developing educational programs and curricula. Turi, Sorooshian, Ghani, Javed, and Ali (2017) stated that information from the industry regarding the qualification standards help to assist educational institutions in formulating policies and improving performance.

To develop cooperation, build images, and improve education services, all schools and universities enhance its management by hiring Public Relations (PR). Practitioners define PR as a typical management function that serves to build and maintain mutualistic relationships and cooperation between organizations and the public. Meanwhile Ferguson (2018) argued that public relations are an activity of creating understanding through knowledge, and these activities are expected to have a positive impact. Another view is stated by Moore (2005) in which PR runs a program in order to gain understanding, acceptance, and cooperation. In addition, the core findings from a program of research focused on examining the structure of public relations/communication departments by Moss, Likely, Sriramesh, and Ferrari (2017) revealed that PR is a management function that plays a role in decision making. Rubin, Rubin, Graham, Perse, and Seibold (2009) wrote an essay that explored the importance of organizational communication with the public to achieve organizational goals. Fajri (2017) concluded that communication plays an important role dealing with maintaining good relations between organizations and the public.

Hiring a quality PR practitioner has become a commitment for educational institutions to deal with the increasingly tight competition. Organizational commitment is related to many factors: educational policy, technological advancement, and seriousness in establishing cooperation (Buda \& Ling, 2017). Thus, every educational institution must take concrete efforts in order to increase their PR practitioner skills so that they have good competencies. Guo and Anderson (2018) said that public relations practitioners face workplace challenges as they cultivate public relationships, resolve conflicts, and manage crises.

The duty of a PR practitioner is no longer limited to provide information services, but it becomes wider, namely to foster harmonious relations with internal and external publics. Thus, due to the important role of public relations 


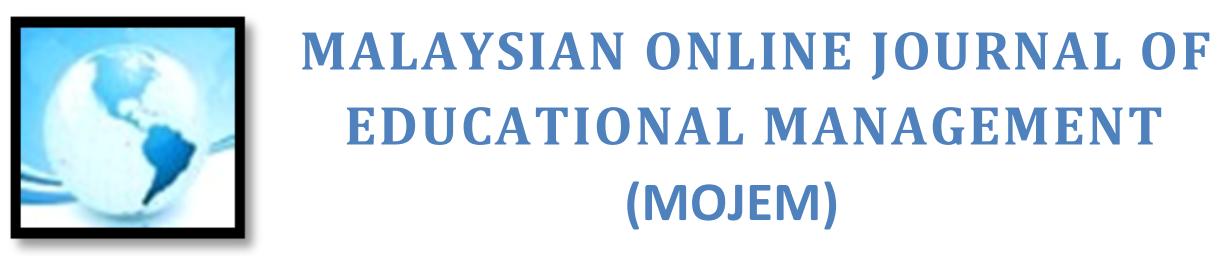

in educational institutions, their quality must be maintained. If the PR practitioner's quality is well maintained, their contribution towards the educational institutions will be more satisfactory.

Due to the important role of PR in enhancing the success of the educational institution management, the institutions should maintain the quality of their performance. By doing so, they will provide a great contribution to the institutions. To realize this, a continuous evaluation of the PR practitioner performance is badly needed to obtain the latest information that describes their level of performance. This continuous evaluation is expected so that any decrease in performance can be revealed immediately in order to be dealt with appropriate actions. This is in line with the results of the research conducted by Peleyeju and Ojebiyi (2013) which recommended that educational institution management must perform a thorough and continuous assessment to measure employees' performance in order to improve their quality and the quality of management in a whole. Continuous evaluation requires an instrument that can be used to better describe public relations practitioner performance. Therefore, it is necessary to develop an evaluation instrument to asses PR practitioners' performance accurately and reliably. Operationally, the objectives of this research are including: (1) developing components and indicators of PR performance evaluation instruments, (2) developing valid and reliable instruments, and (3) producing feasible instruments based on the readability level criteria. The conceptual framework of this research is that educational institutions have improved their management by hiring public relation practitioners to foster cooperation, build images, and improve the quality of education. Therefore, the performance of this PR practitioner needs to be evaluated. To do so, evaluation instruments need to be developed. This evaluation instrument may help ease the conduct evaluations of educational institutions and the industry as well.

\section{CONCEPTUAL FRAMEWORK}

This research intends to design and develop feasible instruments used to evaluate the performance of public relation practitioners in educational institutions in Indonesia. Various researches and evaluations on the performance of professional workers has reinforced the importance of performing an evaluation in order to obtain information which can reveal the success of work accomplishment. Those researches include a research conducted by Mizikaci (2006) which revealed that ideally all educational programs need to be evaluated to know the performance and quality of educational programs such as: excellent quality, quality as zero errors, and quality as transformation. Meanwhile, a study carried out by Calvo-Porral, Lévy-Mangin, and Novo-Corti (2013) mentioned that traditionally, educational institutions are required to perform evaluations which aim at improving the quality of all education services in order to increase student and community satisfaction. In addition, the research findings of Khalaf and Khourshed (2017) alongside Pedro, Mendes, and Lourenço (2018) explained that evaluation aims to obtain information about the quality of services in educational institutions. To evaluate, instruments are required (Mardapi, 2005; Johnson \& Christensen, 2008).

The development of instruments has been extensively studied. Shavelson and Towne (2011) suggested to elaborate components and indicators that can describe the object of evaluation. Suwatno (2018) said that there are three important dimensions to measure the performance of public relations practitioners in educational institutions, namely internal performance to improve motivation, external performance to build cooperation, ethical performance to maintain cultural values. Similar views were expressed by Tench and Yeomans (2009) stating that the performance of public relations practitioners can be measured from the quality of internal and external communication. Internal communication includes corporate communication, business communication, issue management, copywriting, and event organizers. External communication consists of community relations, media relations, and customer relations. The instrument developed in this research is in the form of inventory. Inventory is a non-test instrument consisting of a list of statements and questions that must be selected or filled based on the individual conditions of the respondents (Carlier et al., 2017). Furthermore, inventory is a collection of statements to measure a system of personality, attitude, activity, perception, and behaviour (López, Jódar, \& MacDonald, 2017). 


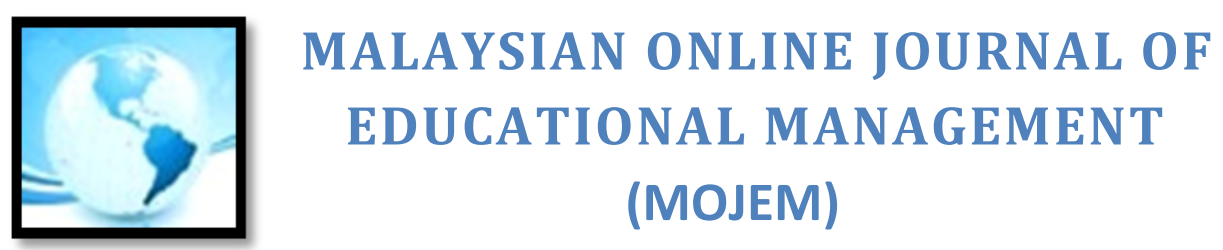

Based on the previous research results, Figure 1 showed a conceptual framework designed to describe the thinking flow of instrument development in this research.

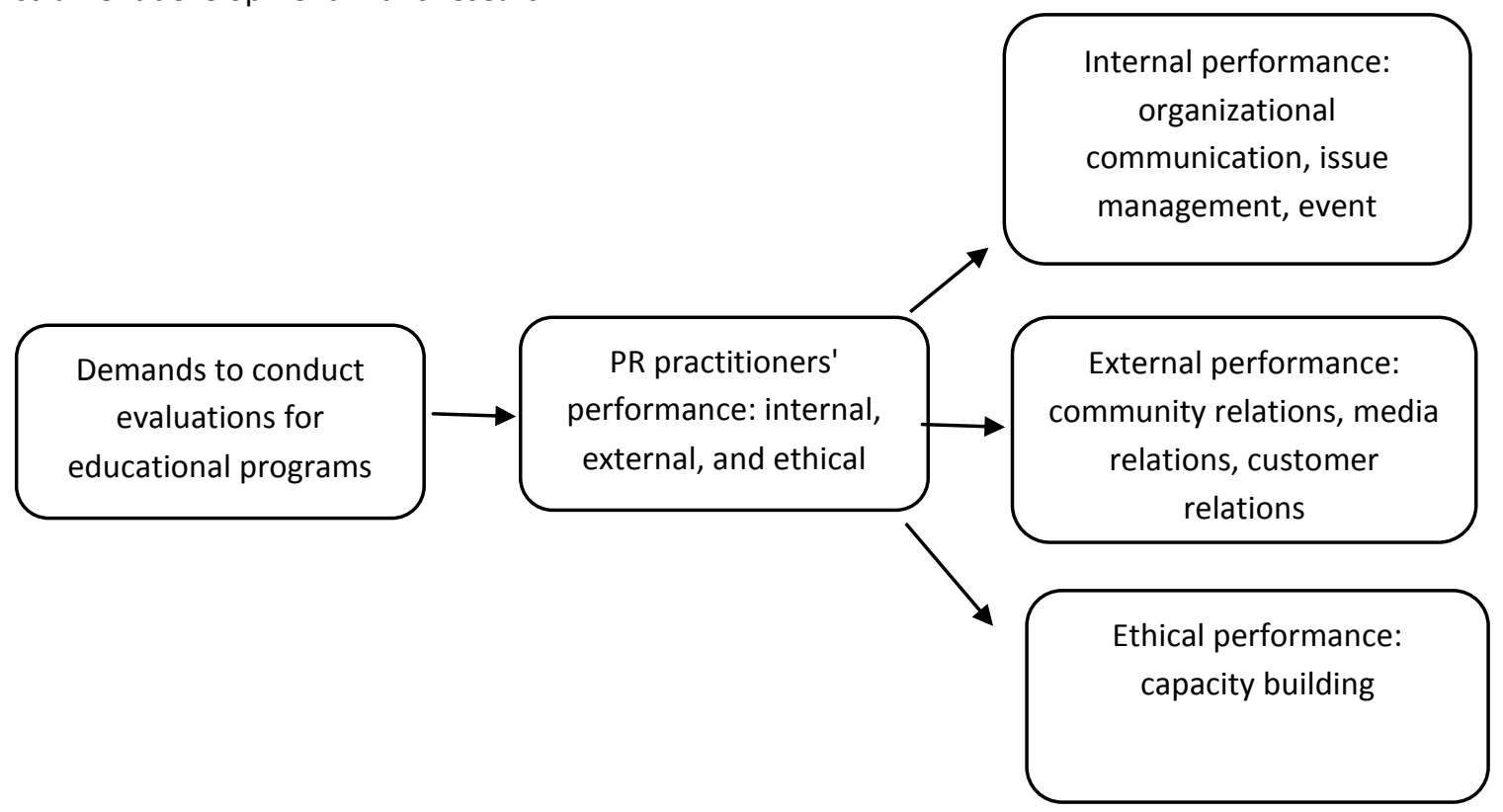

Figure 1. The Conceptual Framework in this Study

\section{LITERATURE REVIEW}

\section{The Evaluation Instruments}

Evaluation is a series of activities in improving the quality, performance, or productivity of an institution in carrying out its program. Through evaluation, information regarding the performance of the institutions can be revealed. Then, this information is used to improve a particular program or activity. Oriondo and Antonio (1998) said that evaluations is a process of summing up the results of measurements or tests, giving them some meaning based on value judgement or the process of concluding the measurement results or tests by giving meaning based on value determination. Stufflebeam (2002) stated that operationally evaluation is the process of delineating, obtaining, reporting, applying descriptive and providing useful information to guide decision making.

The assumption in this research is that the performance of a program, activity, or work needs to be evaluated to examine the success of their implementation. Evaluation is needed to know the PR practitioners' performance in educational institutions therefore the evaluation can provide information that can be used by school leaders and universities for the improvement of the program implementation in the future. Based on some literature (Cullingford, 1997; Mardapi, 2005; Ebel \& Frisbie, 1986; Johnson \& Christensen, 2008), some advantages of performing an evaluation include producing a method for assessing the program and work to know whether they have been carried out in accordance desired goals, providing a means to look back on whether a program and work have been implemented in accordance with the plan and have achieved the results as expected, and providing information that can be used to determine the right alternative in making a decision. To sharpen the discussion about the success of program implementation and performance, van der Knaap (2017) suggests that, more specifically, we can distinguish at least three dimensions of success: (1) the fulfilment of a plan - achieving something intended; (2) acknowledgment by others; and (3) social and societal value. 


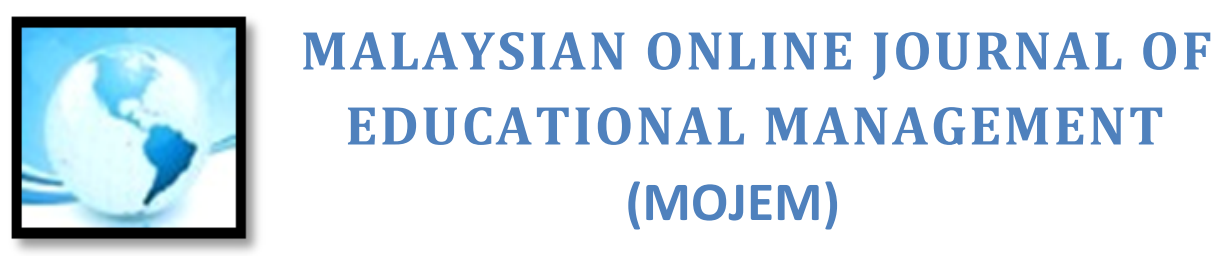

Based on the results of the preliminary survey, one of the obstacles in implementing PR practitioner performance evaluations in educational institutions was the unavailability of evaluation instruments. Mertens (2014) says that the important stages in the evaluation include preparing data collection instruments, using data collection strategies, determining where the data will be obtained (sampling), deciding when information is collected and determining how to analyse data. Based on this view, it can be affirmed that the instrument for collecting data is an important tool in evaluation.

Mardapi (2005) explains that the steps taken for preparing and developing instruments are as follows: (1) formulating variable constructs, namely to build understanding of a concept formulated by the evaluator, based on the synthesis of theories about the concepts of the variables to be measured, (2) developing components and indicators of variables based on the construct, (3) developing an instrument blueprint in the form of a specification table containing components / dimensions, indicators, item numbers, and number of items for each dimension and indicator, (4) determining the amount or parameter that moves in a continuum range from one side to the other opposite side, for example from low to high, from negative to positive, (5) writing instrument items in the form of statements or questions about characteristics or circumstances, attitude or perception, (6) performing validation both theoretical and empirical validation, (7) revising, (8) testing the validity if the content of the items is considered valid or meets the requirements, then instrument becomes the final instrument that will be used to measure the evaluation variables.

The instrument developed in this research is an inventory instrument. Inventory is basically an instrument for collecting data that can be classified as a non-test instrument containing a number of statements or questions that must be selected and answered based on the individual conditions of the respondent. Inventory can also be interpreted as a collection of statements deliberately designed to measure personality, attitudes, activities, perceptions, behaviour and so on.

One important step in developing instruments is the development of components / dimensions and indicators. An indicator is anything that clearly and consistently explains the definition. Shavelson and Towne (2011) explains that designing indicators can be carried out by taking several steps which include: conceptualize potential indicator, refine indicator poor, design alternative indicator system options, evaluate the options and begin developing or refining individual indicator. Indicators are designed to provide accurate information about various conditions and provide information on how the components which are evaluated can produce the complete effect. Chamidi (2005) stated that indicators, in the simplest definition, are symptoms that point to a particular issue or condition. There are certain characteristics possessed by effective indicators, namely: (1) relevant, (2) easy to understand, (3) reliable, and (4) based on the data being accessed. In this research, the indicators developed are symptoms that indicate the performance of public relations practitioners in educational institutions.

To assess the effectiveness of an evaluation instrument, it is necessary to examine the components of the effectiveness criteria. Some effectiveness criteria for an evaluation instrument proposed by Kandak and Egen can be adopted. Kandak and Egen in the work of Kaluge (2004) said that, effective instrument in the real evaluation: It must be valid, systematic, and practical. Based on the view above, it is clear that the effectiveness of an evaluation instrument must meet three main criteria, namely valid, systematic and practical. An evaluation instrument model is said to be valid if they are able to assess what will be assessed and measure what will be measured. In addition, an evaluation instrument model is said to be systematic if the evaluation activities using the instruments are carried out regularly and well planned, so that there are no mistakes or errors that can interfere the evaluation results. Moreover, an evaluation instrument model is said to be practical if they are easy to use, economical and capable to achieve the expected results. 


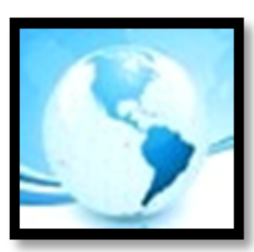

The performance of Public Relations

The instruments developed in this research are intended to evaluate the performance of public relation practitioners in educational institutions. Based on some literature, the definition of the term performance can be obtained. Armstrong (2000) states that, “... it is a record of a person's accomplishments”. Baranik, Wang, Gong, and Shi (2017) say that the outcomes of work because they provide the strongest linkage to the strategic goals of the organisation and customer satisfaction. In addition, Oxford Education Dictionary (2003, p. 317) explains that "(1) performance is the accomplishment, execution, crying out, working out of anything ordered or undertaken. (2) how well or badly you do something or something works". In this definition, Jones, Jenkin, and Lord (2006) said that performance leads to the conclusion that an individual's performance needs to be gauged with both behaviours and outcomes in mind. Another view is expressed by Wihler, Blickle, Ellen, Hochwarter, and Ferris (2017) stating that performance indicators can be broadly described, dealing with the implementation of personal, organizational and public professional duties.

Meanwhile, Soeprijanto (2010) said that the performance of a person in a profession can be measured from the work outcomes in a certain period of time. However, to measure performance, one should also measure the extent to which tasks or work can be carried out based on the requirements. The concept of performance according to Soeprijanto (2010) can be described as follows.

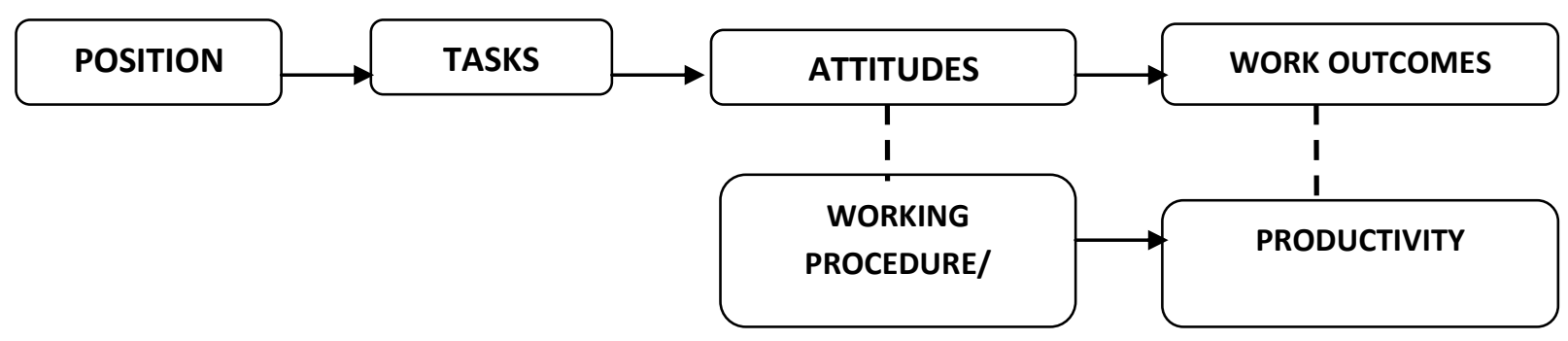

Figure 2. The concept of Performance (Source: Soeprijanto, 2010)

Performance is a total collection of behaviours performed by a worker, thus the performance of public relation practitioner is the process of carrying out work and the results achieved by public relations practitioners in carrying out the tasks assigned to them and the responsibility of public relations practitioners based on skills, experience and sincerity in a certain period of time. Suwatno said that (2018) PR practitioners' performance can be measured from the implementation and indicated by results of public relations programs such as: event management, publicity, public information, community relations, government relations, lobbying.

Moreover, Tench and Yeomans (2009) described in more detail that the PR performance indicators include: internal communication, corporate communication, media relations, business to business, community relations, issue management, copywriting, publication management, event management. Van Thiel and Leeuw (2002) emphasizes that the performance of public relations deal with the ability to manage information and contribute to organizational performance. A broader view was expressed by llinitch, Soderstrom, and Thomas (1998), PR was relied upon to be able to solve various problems from certain environmental conditions. "Interestingly, some popular environmental rating schemes seem to rely more on public reaction to environmental events than on more precise and measurable outcomes or process dimensions" (Ilinitch et al., 1998, p.383). Similar views are described by Freeman (2002) that PR performance indicators are related to the ability to foster good relations with various parties, internal and external environment. 


\section{METHODOLOGY}

\section{Research Approach}

Based on the research objectives, this research employed the Design and Development method, i.e. a method to design and produce certain products and test the effectiveness of the products (Radhakrishna, 2007). To achieve this goal, the researcher mixed quantitative and qualitative approaches. Educational design research blends scientific investigation with the systematic development and implementation of solutions to educational challenges (McKenney \& Reeves, 2018). In this research, the product developed is an evaluation instrument for assessing PR practitioner performance in educational institutions. The evaluation instrument developed in this research is in the form of a rating scale (gradation) referring to the Likert Scale, which is filled by PR practitioners themselves (self-evaluation). Considering that the development of evaluation instruments cannot be separated from the formulation of concepts, components, variable indicators and the instrument item design, the design and development approach is utilized in this research. The development of instruments began with a design, namely writing a conceptual design about the performance of public relations followed by writing blue prints, and instrument items. The procedures for developing the instruments consisted of: (1) developing PR performance constructs, (2) compiling blueprints of PR performance instruments, (3) writing the items of PR performance instruments, (4) validating the contents of instrument items, (5) testing readability of instrument items, (6) revising draft of instrument based on readability test.

\section{Research Subjects}

The subject of this research, in the first stage namely to design instruments, develop components and indicators, included 10 respondents who were chosen purposively consisting of evaluation experts (2 people), and PR practitioners ( 8 people). The second stage involved 12 respondents from public relations practitioners as an assessor or the one who intended to reveal the validity and reliability of the instruments. The third stage, to know the readability of the instrument, involved 50 respondents from PR practitioners taken from 65 members of the research population i.e. Communication Forum of Educational Institutions PR Practitioners in Yogyakarta. The sample size was determined using the Krejcie and Morgan tables with an error rate of 5\% (Leliga, 2013).

\section{Data Collection Techniques}

The data were collected using Focus Group Discussion technique in the first stage and assessment sheet in the second and third stage. Focus Group Discussion (FGD) is implemented to get suggestions and comments from the experts regarding the components and indicators of the instruments. Through this process, recommendations for improving the substance of the instrument were gathered. They include instructions for filling in, clarity of content, terms commonly used in public relations, and the language used.

\section{Data Analysis Techniques}

In this research, the researcher employed FGD and assessment sheet to collect the data. The data taken from FGD were analysed using an interactive analysis of Miles, Huberman, and Saldana (2014). Meanwhile, the data collected from the assessment sheet were used to analyse the validity, reliability and readability of the instrument. To test the validity of instrument items, the researcher used Aiken $V$ formula, with index criteria validity $V$ count $>$ $\vee$ table $=0.75$. The Cronbach Alpha coefficient criteria with at least 0.7 was applied for reliability test to determine the conformity between the results of the assessment carried out by two assessors (rater). The data analysis technique for examining the feasibility of the instrument viewed from the readability aspect is based on the mean score $>3.4-4.2$ out of 5 or in the feasible classification, referring to the conversion of quantitative data to qualitative data on a scale of 5 using formulas that are modified from the formulas developed by Rajab and Sunyoto (2015). These formulas are explained in the table following table: 
Table 1

The Conversion of Quantitative to Qualitative Data

\begin{tabular}{lll}
\hline Formula & Mean score & Classification \\
\hline$X>\mu X_{i}+1,8 \times$ sb $_{i}$ & $>4.2$ & very appropriate/very good \\
$\mu X_{i}+0,6 \times \mathrm{sb}_{\mathrm{i}}<\mathrm{X} \leq \mu \mathrm{X}_{\mathrm{i}}+1,8 \times \mathrm{sb}_{\mathrm{i}}$ & $>3.4-4.2$ & appropriate/good \\
$\mu \mathrm{X}_{\mathrm{i}}-0,6 \times \mathrm{sb}_{\mathrm{i}}<\mathrm{X} \leq \mu \mathrm{X}_{\mathrm{i}}+0,6 \times \mathrm{sb}_{\mathrm{i}}$ & $>2.6-3.4$ & neutral/average \\
$\mu \mathrm{X}_{\mathrm{i}}-1,8 \times \mathrm{sb}_{\mathrm{i}}<\mathrm{X} \leq \mu \mathrm{X}_{\mathrm{i}}+0,6 \times \mathrm{sb}_{\mathrm{i}}$ & $>1.8-2.6$ & slightly appropriate/poor \\
$\mathrm{X} \leq \mu \mathrm{X}_{\mathrm{i}}-1,8 \times \mathrm{sb}_{\mathrm{i}}$ & $\leq 1.8$ & absolutely inappropriate/very poor
\end{tabular}

Note:

$\mu \mathrm{X}_{\mathrm{i}}($ Ideal Mean $)=($ ideal maximum score + ideal minimum score $) / 2$

$\mathrm{Sb}_{\mathrm{i}}$ (Ideal Standard of Deviation) $=1 / 6$ (ideal maximum score - ideal minimum score)

$\mathrm{X}=$ actual score

Validity test of the instrument utilizes content validity based on the expert panel judgement and analysed using the Aiken V formula (Aiken, 1985), with index criteria validity $V$ count $>$ V table $=0.75$. The Aiken's $V$ Index is used to prove content validity based on the results of the expert panel's judgement of each instrument, to what extent the items represent the construct and indicators to be measured through the test instrument. The formula for the Aiken's $V$ Index is presented as Equation 1 below.

$$
\begin{gathered}
\mathrm{s} \\
\mathrm{N}=\sum(\mathrm{c}-1)
\end{gathered}
$$

Where:

$\mathrm{V} \quad$ : index validity

$\mathrm{S} \quad$ : The score set for each rater is reduced by the lowest score of the desired score

c : : The number of categories that can be chosen by rater

$\mathrm{n} \quad$ : The number of rater

Meanwhile, the reliability test is intended to determine the conformity of the evaluation results conducted by two assessors (raters), using the Cronbach Alpha coefficient criteria with at least 0.7.

\section{RESULTS}

This section explains the research results after carrying out an interactive analysis, validity and reliability tests, and an analysis of the instrument readability. Results of the research are presented based on the objectives of the research which include: (1) developing components, indicators, and instrument items for evaluating PR performance in educational institutions, (2) examining the validity and reliability of instruments, and (3) investigating the readability of instruments which has been developed.

\section{Components \& Indicators of Public Relations Practitioner's Performance Evaluation Instruments}

The first step taken to develop the components and indicators of the instrument is to carry out preliminary study activities, namely literature studies, theoretical analysis, relevant research result studies, and FGD. The results of 


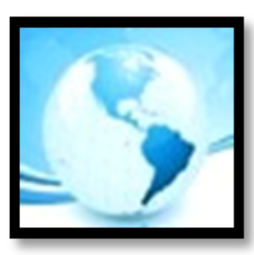

\section{MALAYSIAN ONLINE JOURNAL OF EDUCATIONAL MANAGEMENT (MOJEM)}

the preliminary study were used as materials for designing instrument constructs that include components and indicators. Based on preliminary studies, some points can be presented as follows: (1) In some literature, the term PR can be understood as an organization, profession, and as an activity; (2) The main task of public relations practitioners is to foster relationships or communication with internal and external parties of the organization; (3) Task maps and work of PR practitioners can be classified into three categories: Internal PR, external PR, and capacity building; (4) PR performance needs to be evaluated.

The data collected from literature studies, theoretical analysis, relevant research result studies, and FGD were analysed qualitatively and used as materials for developing drafts of the components and indicators of the instrument. In this research, instruments that are deemed to be suitable with needs are in the form of evaluation instruments filled by PR practitioners themselves (self- evaluation). A development draft of components, indicators, and instruments items which have been developed was validated by public relations practitioners. Basically, the validation process is carried out to get comments, input and suggestions so that the judgment from public relations practitioners can be obtained.

The results of developing PR performance evaluation instruments are measured using three components, namely: (1) Performance in internal public relations (Internal PR), (2) Performance in external public relations (External PR), and (3) Capacity of public relations practitioners. The component developed is still too broad, which can possibly be re-compiled and re-developed into a more detailed and more focused component.

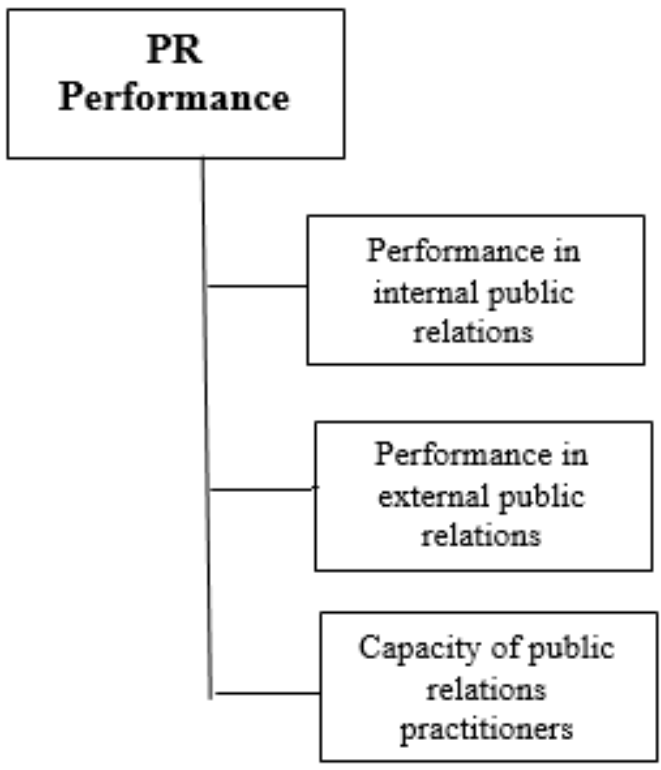

Figure 3. Three components of the PR performance evaluation instruments

Based on these components, indicators and instrument items were developed. The components of internal public relations are measured using four indicators, external PR is measured using three indicators, and PR practitioners' capacity is measured using two indicators. The table of instruments blueprints below illustrates the development of components, indicators, and items of public relations performance instruments. 


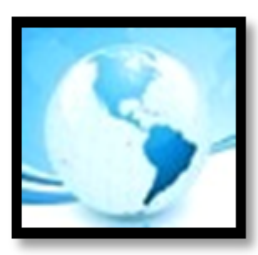

Table 2

The blueprint of an evaluation instrument of $P R$ performance

\begin{tabular}{|c|c|c|}
\hline Components & Indicators & Items (number) \\
\hline \multirow[t]{4}{*}{ Internal $P R$} & Managing information & $1,2,3,4$ \\
\hline & Managing event & $5,6,7,8$ \\
\hline & $\begin{array}{l}\text { Preparing materials for presentation, campaign, } \\
\text { promotion }\end{array}$ & $9,10,11$ \\
\hline & Managing protocol & $12,13,14,15$ \\
\hline \multirow[t]{3}{*}{ External PR } & $\begin{array}{l}\text { Fostering good relations with the community } \\
\text { (community relations) }\end{array}$ & $16,17,18,19,20$ \\
\hline & $\begin{array}{l}\text { Building good relationships with customers (customer } \\
\text { relations) }\end{array}$ & $21,22,23$ \\
\hline & $\begin{array}{l}\text { Developing good relationships with press (press } \\
\text { relations) }\end{array}$ & 24,25 \\
\hline \multirow[t]{2}{*}{ PR practitioners' capacity } & Taking education and training & 26,27 \\
\hline & $\begin{array}{l}\text { Joining the activities of the public relations professional } \\
\text { association }\end{array}$ & 28 \\
\hline
\end{tabular}

Table 2 explains that an evaluation instrument of PR performance developed in this research consists of three components namely, internal PR, external PR and PR practitioners' capacity. Each component is elaborated into indicators and 28 items. Those items are tested their validity and reliability.

\section{Validity \& Reliability of An Evaluation Instrument of PR Performance}

Validity test of instrument items was performed using content validity, namely by using assessment sheets. In this research, the researchers technically used the assessment sheets for PR practitioners in several educational institutions as raters or validators to assess each instrument item. Instrument items are categorized as having content validity if they can measure certain specific objectives that are relevant to the contents of the duties and tasks of PR. Thus, the validator was asked to validate by comparing the contents of each instrument with the description of the duties and tasks they carry out.

The data on the content validity assessment results for 28 items of PR performance evaluation instruments were obtained from the judgment of 12 experts as assessors (raters) or validators. The results of the instrument trials were analysed using the Aiken formula. Instrument items are categorized as valid if the expert believes that the instrument measures the level of performance defined in the validated item. The content validity test uses the Aiken formula referring to the validity index which is obtained by using the Aiken Formula. Based on 12 validators and rating scales of 1 to 5 , the instrument items are categorized as valid if they have an Aiken validity index (Aiken V) greater than $\mathrm{V}$ table $=0.69$. 


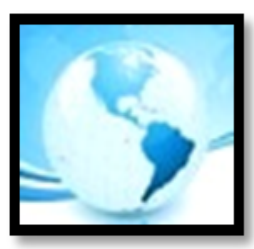

MALAYSIAN ONLINE JOURNAL OF

EDUCATIONAL MANAGEMENT

(MOJEM)

Table 3

A Content Validity Analysis of an evaluation instrument of $P R$ performance

\begin{tabular}{|c|c|c|c|c|c|}
\hline Item & $\Sigma \mathrm{s}$ & $N(c-1)$ & $V$ count & V table & Results \\
\hline & 40 & 48 & 0.83 & 0.69 & Valid \\
\hline & 46 & 48 & 0.96 & 0.69 & Valid \\
\hline & 38 & 48 & 0.79 & 0.69 & Valid \\
\hline & 38 & 48 & 0.79 & 0.69 & Valid \\
\hline & 46 & 48 & 0.96 & 0.69 & Valid \\
\hline & 28 & 48 & 0.58 & 0.69 & Not Valid \\
\hline & 41 & 48 & 0.85 & 0.69 & Valid \\
\hline & 39 & 48 & 0.81 & 0.69 & Valid \\
\hline & 37 & 48 & 0.77 & 0.69 & Valid \\
\hline & 40 & 48 & 0.83 & 0.69 & Valid \\
\hline & 47 & 48 & 0.98 & 0.69 & Valid \\
\hline & 37 & 48 & 0.77 & 0.69 & Valid \\
\hline & 41 & 48 & 0.85 & 0.69 & Valid \\
\hline & 43 & 48 & 0.90 & 0.69 & Valid \\
\hline & 40 & 48 & 0.83 & 0.69 & Valid \\
\hline & 39 & 48 & 0.81 & 0.69 & Valid \\
\hline & 41 & 48 & 0.85 & 0.69 & Valid \\
\hline & 46 & 48 & 0.96 & 0.69 & Valid \\
\hline & 41 & 48 & 0.85 & 0.69 & Valid \\
\hline & 45 & 48 & 0.94 & 0.69 & Valid \\
\hline & 39 & 48 & 0.81 & 0.69 & Valid \\
\hline & 39 & 48 & 0.81 & 0.69 & Valid \\
\hline & 47 & 48 & 0.98 & 0.69 & Valid \\
\hline & 24 & 48 & 0.50 & 0.69 & Not Valid \\
\hline & 44 & 48 & 0.92 & 0.69 & Valid \\
\hline & 40 & 48 & 0.83 & 0.69 & Valid \\
\hline & 40 & 48 & 0.83 & 0.69 & Valid \\
\hline & 41 & 48 & 0.85 & 0.69 & Valid \\
\hline
\end{tabular}

The results of the analysis show that on the trials of 28 instrument items of PR performance evaluation, there are two invalid items indicated by Aiken validity index value of $\mathrm{V}$ count 0.58 and $0.50<\mathrm{V}$ table 0.69 , therefore, those items were dropped. In summary, 26 instrument items were valid, namely items that are able to measure what should be measured. Based on the results of this analysis, 26 items can be used to collect data on the performance of public relations practitioners.

The instrument reliability test was carried out by investigating the conformity of the interrater scores using the Cronbach Alpha coefficient>0.7. The results of the trial show the coefficient of $\alpha=0.978$. It indicates that the instruments developed in this research are reliable. In other words, this instrument has consistency i.e. it is able to provide equal results to assess a person's performance even though it is carried out by two different raters. Based on the results of the validity and reliability test, it is confirmed that this instrument can be used to help ease the educational institutions and industries to conduct performance evaluations of public relations practitioners. 


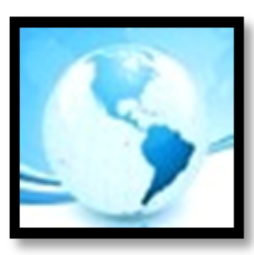

MALAYSIAN ONLINE JOURNAL OF

EDUCATIONAL MANAGEMENT

(MOJEM)

The Readability of Instruments

The readability test of the instrument is based on the results of the validation (judgement) of public relations practitioners who provide inputs to improve the instruments. In this research, the readability of the instrument is one of the criteria to determine the feasibility of the instrument, meaning that if the instrument has a good level of readability, then the instrument is categorized as feasible to use.

Assessment on the readability of the instrument is directed at the aspects of clarity of instrument instructions, clarity of PR performance indicators, language used, and writing procedures. Judgement is performed using multilevel scale scores with maximum score of 5 . Judgement on language aspects is directed at: 1) the use of standard Indonesian language, and 2) formulation of communicative statements. Judgement on grammar is directed at: 1) type of font, 2) font size, and 3) punctuation marks. The instrument readability test in this research was carried out by sending an instrument bundle which has been developed along with the assessment questionnaire. Respondents were invited to validate by giving an assessment of the quality of the instrument and giving suggestions and opinions. Validation of instrument readability in the trial involved 50 people. The results of the full assessment on the readability of the instrument are presented as follows:

Table 4

The readability of an evaluation instrument of $P R$ performance

\begin{tabular}{lll}
\hline No. & Evaluation Aspects & Mean score \\
\hline 1 & Clarity of instrument instructions & 3.95 \\
\hline 2 & Clarity of PR performance indicators & 3.95 \\
\hline 3 & Use of standard Indonesian language & 3.85 \\
\hline 4 & Formulation of communicative statements & 3.80 \\
\hline 5 & Type of fonts & 3.95 \\
\hline 6 & Font size & 3.80 \\
\hline 7 & The use of punctuation marks & 4.05 \\
\hline Mean of Total Score & 3.91 \\
\hline
\end{tabular}

Based on the rules of converting quantitative to qualitative data as presented earlier, it shows that the readability mean score of the communication skills evaluation instrument is 3.91 from a maximum score of 5 , in the mean score range $>3.4-4.2$. It means that the readability of the instrument falls into the classification of feasible (with minor revisions). Thus, it can be concluded that judging from the level of readability, the instruments developed in this research are classified as feasible to use. Rationally, instruments that meet the readability criteria will be easier to use. For respondents, they will not find difficulties to understand the direction of the question or statement on each item. Thus, the data collected by the evaluator can describe the actual situation. The availability of reliable instruments will produce good data as well.

\section{IMPLICATION OF THE FINDINGS}

Various researches and studies have revealed the importance of evaluation instrument as a tool to collect data. In addition, some previous empirical studies have reinforced that the instruments can help ease leaders of educational institutions to evaluate the performance and success of educational program implementation. This research has succeeded in developing a set of feasible instruments used to evaluate the performance of public relation practitioners in educational institutions. 


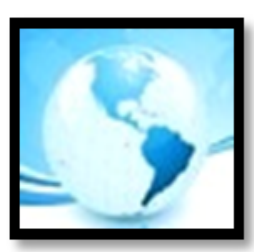

\section{MALAYSIAN ONLINE JOURNAL OF EDUCATIONAL MANAGEMENT (MOJEM)}

This finding, theoretically, adds knowledge unto components and indicators for measuring PR performance variables. The practical findings of this study provide the basis for further research to develop more comprehensive instruments. Furthermore, it practically reduces doubts among educational policy makers to implement evaluations and improve public relations performance in educational institutions. Viewed from the scope of the study, there has been no research which specifically develops PR performance evaluation instruments in educational institutions so far. In addition to widening theoretical insights, this research also strengthens the application of empirical evaluation. Thus, it will help policy makers to conduct ongoing evaluations to reveal the public relations performance in educational institutions in Indonesia. With continuous evaluation, useful information will be obtained as consideration to improve public relations performance in educational institutions.

\section{DISCUSSION AND CONCLUSION}

The results of the development of PR performance evaluation instruments reveal that the performance of public relations was evaluated through three components, namely: (1) fostering good relations with the internal public (internal PR); (2) building good relations with the external public (external PR), and (3) developing the capacity of public relations practitioners. The findings of these three components are relevant to the theory proposed by Suwatno (2018) and Freeman (2002) stating that PR performance indicators deal with the ability to foster good relations with various parties both internal and external. The third component included in the instruments reveals the development of PR practitioners' capacity. PR capacity building is not only the right of public relation practitioners but also the obligation of public relation practitioners to increase their contribution to the institution. The role of capacity building component supports the theory developed by Van Thiel and Leeuw (2002) that increasing the capacity of public relations practitioners contributes to organizational performance.

The PR performance evaluation instrument developed in this research is an evaluation instrument that is quite simple in its implementation, but complete information can be revealed through this instrument. Therefore, it can be applied by organizations or companies to conduct PR performance evaluations. This instrument is an instrument completed by PR practitioners themselves (self-evaluation). This evaluation instrument has been tested and the results show that the instrument has feasibility in terms of readability. The quantitative test results, analysed using the item validity test employing the Aiken formula and reliability test with Cronbach Alpha Coefficient criteria, show that the items developed are categorized as valid (there are only two invalid items from 28 items being analysed) and therefore the instruments are reliable. The instruments which have met the feasibility criteria (valid, reliable, and readable) can be used by principals and university leaders to evaluate the performance of PR practitioners in their institutions. Ideally, each education program must be evaluated to determine the success of its implementation. With this instrument, leaders of educational institutions can conduct evaluations easily.

Some limitations of this research include the following: (a) The PR performance evaluation instruments developed in this study includes three components. However, it is still possible to have more PR performance components that are important to assess but still uncovered in this research, especially in the context of the unique and special environment and conditions; (b) the evaluation instrument developed in this research is a self-evaluation model, where PR practitioners evaluate their own performance. Thus, the evaluation process has not involved an independent appraisal from outside the PR practitioner, such as an evaluation by the leader. Because it only relies on evaluations from internal parties (internal appraisal), it is possible to reduce the level of objectivity of the evaluation results. Despite the limitations, this instrument is good for describing the performance of public relations practitioners. Moreover, the information about their performance can be used by policy makers to make decision. This is supported by the view of Kurniawan, Muslim, and Sakapurnama (2018) stating that evaluation can contribute to the policy-making. In addition, Noordegraaf (2017) has argued that our own evaluation is used as a reflexive case study: not to present findings but to discuss the challenges we faced and the lessons we learned as evaluators. 


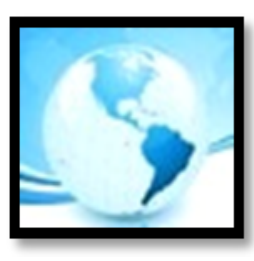

\section{MALAYSIAN ONLINE JOURNAL OF EDUCATIONAL MANAGEMENT (MOJEM)}

Based on the research results, the important conclusion are that instruments which could ease leaders of educational institutions evaluate the performance of public relations has been developed. The characteristics of the instrument are as follows. The components of public relations performance in this research include: (a) fostering good relations with the internal public (internal PR); (2) building good relations with the external public (external PR), and (3) developing the capacity of public relations practitioners. The results of the trial showed that 26 items which have been developed have met the validity and reliability, so that it is appropriate to be used by teachers to evaluate the performance of public relations practitioners. The instrument readability test results showed the PR performance evaluation instrument belongs to the category of good or feasible to use.

\section{REFERENCES}

Aiken, L. R. (1985). Three coefficients for analysing the reliability and validity of ratings. Educational and Psychological Measurement, 45(1), 131-142.

Ansari, M. N. (2017). List of recently published quality research papers. Imperial Journal of Interdisciplinary Research, 3(8), 32-44.

Armstrong, M. (2000). Performance management. London: Kogan Page.

Baranik, L. E., Wang, M., Gong, Y., \& Shi, J. (2017). Customer mistreatment, employee health, and job performance: Cognitive rumination and social sharing as mediating mechanisms. Journal of Management, 43(4), 12611282.

Buda, A. A., \& Ling, Y. L. (2017). The relationship between transformational leadership and organizational commitment in Polytechnic Kuching Sarawak. Malaysian Online Journal of Educational Management (MOJEM), 5(4), 35-46.

Calvo-Porral, C., Lévy-Mangin, J. P., \& Novo-Corti, I. (2013). Perceived quality in higher education: An empirical study. Marketing Intelligence \& Planning, 31(6), 601-619.

Carlier, I. V., Kovács, V., van Noorden, M. S., van der Feltz-Cornelis, C., Mooij, N., van Maaren, Y. W., ... \& Giltay, E. J. (2017). Evaluating the responsiveness to therapeutic change with routine outcome monitoring: $A$ comparison of the Symptom Questionnaire-48 (SQ-48) with the Brief Symptom Inventory (BSI) and the Outcome Questionnaire-45 (OQ-45). Clinical psychology and Psychotherapy, 24(1), 61-71.

Chamidi, S. (2005). Makna dan Aplikasi Sederhana Indikator Pendidikan [Meaning and Simple Application of Educational Educators]. Jakarta: Departemen Pendidikan Nasional, Badan Pendidikan dan Pengembangan, Pusat Data dan Inforamasi Pendidikan, Bidang Pendayagunaan Data dan Informasi [The Ministry of Education, the Agency for Education and Development, the Data Center and the Education Information, the Field of Information and Information Empowerment.].

Cullingford, C. (1997). Assessment versus evaluation. London: Cassell.

Ebel, R. L., \& Frisbie, D. A. (1986). Essential of educational measurement. New Jersey, USA: Prentice- Hall, Inc.

Fajri, C. (2017). Peran humas dalam meningkatkan loyalitas stakeholders Universitas Ahmad Dahlan [The role of public relations in increasing the loyalty of Ahmad Dahlan University stakeholders]. Jurnal Informasi, 47(1), 97-108. 


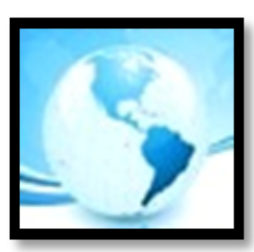

\section{MALAYSIAN ONLINE JOURNAL OF EDUCATIONAL MANAGEMENT (MOJEM)}

Ferguson, M. A. (2018). Building theory in public relations: Interorganizational relationships as a public relations paradigm. Journal of Public Relations Research, 30(4), 164-178.

Freeman, T. (2002). Using performance indicators to improve health care quality in the public sector: a review of the literature. Health Services Management Research, 15(2), 126-137.

Guo, S. J., \& Anderson, L. B. (2018). Workplace adversity and resilience in public relations: Accounting for the lived experiences of public relations practitioners. Public Relations Review, 44(2), 236-246.

Ilinitch, A. Y., Soderstrom, N. S., \& Thomas, T. E. (1998). Measuring corporate environmental performance. Journal of Accounting and Public Policy, 17(4-5), 383-408.

Johnson, B., \& Christensen, L. (2008). Educational research quantitative, qualitative, and mixed approaches. Los Angeles: SAGE Publishing.

Jones, J., Jenkin, M., \& Lord, S. (2006). Developing effective teacher performance. California: SAGE Publishing.

Kaluge, A. H. (2004). Pengembangan model penilaian proses belajar matematika yang komprehensif dan kontinu pada pembelajaran kooperatif di SMP [Developing a comprehensive and continous assessment model for Mathematics cooperative learning at SMP]. [Unpublished doctoral dissertation]. Universitas Negeri Surabaya, Indonesia.

Khalaf, M. A., \& Khourshed, N. (2017). Performance-based service quality model in postgraduate education. International Journal of Quality \& Reliability Management, 34(5), 626-648

Kurniawan, T., Muslim, M. A., \& Sakapurnama, E. (2018). Regulatory impact assessment and its challenges: An empirical analysis from Indonesia. Kasetsart Journal of Social Sciences, 39(1), 105-108.

Leliga, F. J. (2013). Analisa pengaruh brand image terhadap customer loyalty dengan customer satisfaction sebagai mediator pada the Dreamland Luxury Villas and Spa, Bali [The analysis of brand image Influences on customer loyalty and customer satisfaction as mediator in Dreamland Luxury Villas and Spa, Bali]. Jurnal Hospitality dan Manajemen Jasa, 1(1), 80-93.

López, E., Jódar, R., \& MacDonald, D. A. (2017). Psychometric properties of a Spanish adaptation of the Expressions of Spirituality Inventory-Revised (ESI-R). International Journal of Transpersonal Studies, 36(1), 11-24

McKenney, S., \& Reeves, T. C. (2018). Conducting educational design research. London: Routledge.

Mertens, D. M. (2014). Research and evaluation in education and psychology: Integrating diversity with quantitative, qualitative, and mixed methods (4th ed.). USA: SAGE Publications.

Miles, M. B., Huberman, A. M., \& Saldana, J. (2014). Qualitative data analysis. USA: SAGE Publications.

Mizikaci, F. (2006). A systems approach to program evaluation model for quality in higher education. Quality Assurance in Education, 14(1), 37-53.

Moore, H. F. (2005). Humas membangun citra dengan komunikasi [Public relations build images with communication]. Bandung: Remaja Rosdakarya. 


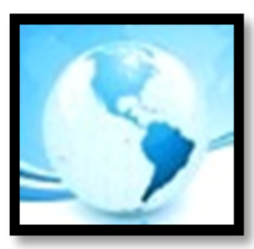

\section{MALAYSIAN ONLINE JOURNAL OF EDUCATIONAL MANAGEMENT (MOJEM)}

Moss, D., Likely, F., Sriramesh, K., \& Ferrari, M. A. (2017). Structure of the public relations/communication department: Key findings from a global study. Public Relations Review, 43(1), 80-90.

Narayanan, A., \& Nandi, E. (2017). Do skilled workers have decent jobs? Indian Journal of Human Development, 11(1), 124-132.

Noordegraaf, M., Douglas, S., Bos, A., \& Klem, W. (2017). How to evaluate the governance of transboundary problems? Assessing a national counterterrorism strategy. Evaluation, 23(4), 389-406.

Mardapi, D. (2005). Teknik penyusunan instrumen tes dan nontes [Techniques of Developing Test and Non-Test instruments]. Yogyakarta: Mitra Cendikia Offset.

Oriondo, L. L., \& Antonio, E. M. D. (1998). Evaluating educational outcomes: Tests, measurement and evaluation. Florentino St: Rex Printing Company.

Pedro, E., Mendes, L., \& Lourenço, L. (2018). Perceived service quality and student's satisfaction in higher education: the influence of teaching methods. International Journal for Quality Research, 12(1), 165192.

Peleyeju, J. O., \& Ojebiyi, O. A. (2013). Lecturers' performance appraisal and total quality management of public universities in South-Western Nigeria. British Journal of Education, 1(2), 41-47.

Petrovskiy, I. V., \& Agapova, E. N. (2016). Strategies of raising the quality of higher education and attaining equality of educational opportunities. International Journal of Environmental \& Science Education, 11(9), 256272.

Radhakrishna, R. B. (2007). Tips for developing and testing questionnaires/instruments. Journal of Extension, 45(1), 1-4.

Rajab, A., \& Sunyoto, A. (2015). Pengembangan media pembelajaran menerapkan teknik elektronika analog dan digital dasar [Development of instructional media applying basic analog and digital electronics engineering]. Jurnal IImiah Teknologi Informasi, 5(2), 9-17.

Rubin, R. B., Rubin, A. M., Graham, E. E., Perse, E. M., \& Seibold, D. R. (2009). Communication research measures. New York: Routledge.

Shavelson, R. J., \& Towne, L. (2011). What drives scientific research in education? APS Observer, 17(4), 82-96.

Soeprijanto. (2010). Pengukuran kinerja guru praktik kejurua: Konsep dan teknik pengembangan instrumen [Measurement of practice teachers' performance: Concepts and techniques for developing instruments]. Jakarta: CV Tursina.

Stufflebeam, D. L. (Ed.). (2002). Evaluation models. New York: Kluwer Academic Publisher.

Suwatno. (2018). Pengantar public relations kontemporer [Introduction to contemporary public relations]. Bandung: PT. Remaja Rosdakarya.

Tench, R., \& Yeomans, L. (2009). Exploring public relations. Harlow: Prentice Hall. 


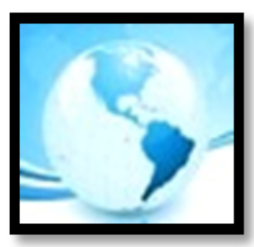

\section{MALAYSIAN ONLINE JOURNAL OF EDUCATIONAL MANAGEMENT (MOJEM)}

Turi, J. A., Sorooshian, S., Ghani, M. F. A., Javed, Y., \& Ali, A. (2017). Organizational learning: Prospective on employees readiness using information system supported learning. Malaysian Online Journal of Educational Management (MOJEM), 6(1), 68-94.

van der Knaap, P. (2017). Positive evaluation and learning: Looking for 'Success' in Netherlands road safety policy. Evaluation, 23(4), 432-443.

van Thiel, S., \& Leeuw, F. L. (2002). The performance paradox in the public sector. Public Performance \& Management Review, 25(3), 267-281.

Wihler, A., Blickle, G., Ellen, B. P., III., Hochwarter, W. A., \& Ferris, G. R. (2017). Personal initiative and job performance evaluations: Role of political skill in opportunity recognition and capitalization. Journal of Management, 43(5), 1388-1420.

Zaki, S., \& Rashidi, M. Z. (2013). Parameters of quality in higher education: A theoretical framework. International Journal of Social Sciences \& Education, 3(4), 65-81. 